\title{
Killing of mice by rats prevented by early interaction between the two species'
}

VICTOR H. DENENBERG, RICHARD E. PASCHKE ${ }^{2}$, AND M. X. ZARROW, DEPARTMENTS OF PSYCHOLOGY AND BIOLOGICAL SCIENCES, PURDUE UNIVERSITY, Layfayette, Ind. 47907

Forty control male rats were exposed to mice for the first time as adults; 18 (45\%) killed one or two mice. Twenty experimental male rats lived with mice from 21 to 57 days of age and were later exposed to strange mice; no mice were killed. The implications of the findings for instinct theory and the "deprivation experiment" are discussed.

A common laboratory observation is that an adult rat is likely to attack and kill a mouse placed into a cage with the rat (Myer, 1964; Myer \& Baenninger, 1966). This is a spontaneous event which occurs the first time that the rat sees the mouse. Since the killing response occurs in the absence of any prior experience with mice, and in the absence of any other form of prior experience with killing, this behavior meets the classical operational definition for an instinctive response (Eibl-Eibesfeldt, 1961; Lorenz, 1965). However, in a series of experiments in which we have raised rats and mice together from weaning, we have had virtually no incidence of rats killing mice (Denenberg, Hudgens, \& Zarrow, 1964, 1966; Hudgens, Denenberg, \& Zarrow, 1967). Because of the implications of our observations for classical instinct theory as well as for concepts concerning early socialization (Scott, 1962), we carried out an experiment to verify our findings in a controlled fashion.

Procedure. The experimental Ss were male Purdue-Wistar rats born and reared in a standard maternity cage until weaning in 21 days. At that time control rats were placed into groups of approximately 10 per cage where they remained until testing. They were never exposed to mice at any time until testing.

The experimental males were housed at weaning with C57BL/10 mice in social groups which consisted of two rats and two mice, or three rats and one mouse. When the animals were placed together at weaning observations were taken with respect to whether any of the rats killed any mice. At 57 days of age the mice were removed and the experimental rats were regrouped into units of 10 each in the same type of cages as the control males.

Starting at 90 days of age each rat was tested twice with a mouse. In each test one rat and one mouse were placed together into a plastic cage and were left for $24 \mathrm{~h}$. Each rat was exposed to one black mouse (C57BL/10) and one white mouse (Rockland-Swiss albino). Half the rats were exposed to the black mouse first, the other half to the white mouse. Records were kept of the number of mice killed.

Results and Discussion. At 21 days of age one of 20 rats killed a mouse (5\%). Another rat was substituted for this one; he did not kill at 21 days. At the 90 -day test 18 of $40(45 \%)$ control males killed one or two mice. Fourteen killed two mice; of the other four, one killed a white mouse and three killed black mice. Therefore, there was no difference in killing response to the black or white mouse. In contrast to this, none of the 20 experimental males killed any mice $(p<0.01)$.

The results demonstrate that the spontaneous "unlearned" response of mouse killing by the rat can be eliminated by early social interaction between the two species. Furthermore, this phenomenon will generalize to a very different subline within that species as shown by the fact that the experimental rats would not kill the white mice either, although their early social experience had only been with black mice. Finally, the data suggest that this change in behavior may be relatively permanent since the experimental rats were removed from the mice at 57 days of age and kept away from mice for 33 days before the tests for mouse killing began.

Our control rats met all the requirements of the classical deprivation experiment which has been specified as the sine qua non for the definition of an instinctive behavior (Lorenz, 1965). They killed mice. Our experimental animals were exposed to mice for 36 days during early development and then separated from them for 33 days before being tested. They did not kill mice. It is obvious, therefore, that the concept of instinct is insufficient to account for these data, and it is also apparent that the deprivation experiment is not a sufficient condition to define instinctive behavior. Indeed, the conditions under which we reared our control rats are essentially the same as those under which Eibl-Eibesfeldt (1961) reared his polecats. He, too, found that the killing response occurred. However, in order to understand an animal's behavior not only is it necessary to subtract experiences, as in the deprivation experiment, but it is also necessary to add experiences as we did with our experimental group. This was the procedure followed by Kuo $(1930,1938)$ in his studies of rat killing by cats.

It is only when a specific behavior pattern occurs in the same general form under a wide variety of environmental conditions that one can logically speak of that behavior as being instinctive (Ross \& Denenberg, 1960). However, rather than use an instinct-learning classification, we feel that a more fruitful approach to an understanding of behavior is within a developmental framework in which the organism's behavior at any point in time is viewed as a function of the animal's accumulated experiences as well as his genetic background.

\section{REFERENCES}

DENENBERG, V. H., HUDGENS, G. A., \& ZARROW, M. X. Mice reared with rats: Modification of behavior by early experience with another species. Science, 1964, 143, 380-381.

DENENBERG, V. H., HUDGENS, G. A., \& ZARROW, M. X. Mice reared with rats: Effects of mother on adult behavior patterns. Psychol. Rep., $1966,18,451-456$

EIBL-EIBESFELDT, $\mathrm{l}$. The interaction of unlearned behavior patterns and learning in mammals. In J. F. Delafresnaye (Ed.), Brain mechanisms and learning. London: Blackwell, 1961. Pp. 53-74.

HUDGENS, G. A., DENENBERG, V. H., \& ZARROW, M. X. Mice reared with rats: Relations between mothers' activity level and offspring's behavior. J. comp. physiol. Psychol, 1967, 63, 304-308.

KUO, Z. Y. The genesis of the cat's response to the rat. J. comp. Psychol., $1930,11,1-35$.

KUO, Z. Y. Further study on the behavior of the cat toward the rat. J. comp. Psychol., 1938, 25, 1-8.

LORENZ, K. Evolution and modification of behavior. Chicago: University of Chicago Press, 1938.

MYER, J. S. Stimulus control of mouse-killing rats. J. comp. physiol. Psychol., 1964, 58, 112-117.

MYER, J. S., \& BAENNINGER, R. Some effects of punishment and stress on mouse killing by rats. J. comp. physiol. Psychol., 1966, 62, 292-297.

ROSS, S., \& DENENBERG, V. H. Innate behavior: The organism in its environment. In R. H. Waters, D. A. Rethlingshafer, \& W. E. Caldwell (Eds.), Principles of comparative psychology. New York: McGraw-Hill, 1960. Pp. 43-73.

SCOTT, J. P. Critical periods in behavioral development. Science, 1962,138 , 949-958.

\section{NOTES}

1. This research was supported, in part, by Research Grant HD-02068 from the National Institute of Child Health and Human Development.

2. Supported by NIH Training Grant 1 T1 MH-10267. 